\title{
Two Years Later: Natureza \& Conservação and its Impact
}

\author{
Rafael Dias Loyola* \\ (Deputy Editor-in-Chief, Natureza \& Conservação) \\ José Alexandre Felizola Diniz-Filho \\ (Editor-in-Chief, Natureza \& Conservação)
}

In the editorial that officially launched Natureza \& Conservação (The Brazilian Journal of Nature Conservation, henceforth $\mathrm{N} \& \mathrm{C}$ ) as a publication of the Brazilian scientific society,ABECO (Associação Brasileira de Ciência Ecológica e Conservação, the Brazilian Society for Ecological Science and Conservation - www.abeco.org.br), we pledged a journal that would publish scientifically sound papers that, hopefully, may provide solid background for decision-makers and effective conservation practice (Diniz-Filho \& Loyola 2010). Since then, we have prioritized publication of studies that use general scientific principles and are of broad conservation interest, promoting the integration among researchers working in different environments, with distinct groups of organisms, and at multiple geographical and hierarchical levels. We believe that now is a good time to evaluate how we have done in the first two volumes.

The four issues of the first two volumes (vols. 8 and 9) comprise 64 papers published by authors from Brazil and several other countries (e.g. Argentina, Australia, Colombia, Germany, Italy, New Zealand, Portugal, Spain, USA). Of the total submissions, $15 \%$ were rejected without review, and $c a .20 \%$ after review. We feel the quality and speed of the review process has been good. As a distinctive feature, our average review time to reach a first decision was only 34 days (median of 28 days).

In July 2011 we had an impact factor (IF) of 0.56 , which was higher than the first one received by the journal $(\mathrm{IF}=0.24$, in 2010). Now, in July 2012, we reached an impact factor of 1.05 , a doubling pattern despite the small number of issues. This figure indicates that conservation and biodiversity research is booming - especially in Brazil - not only in terms of scientific quality, but also in terms of their real world impact.

Brazil has the largest research and graduate school system in Latin America and the Caribbean, and its success can be credited to the implementation of a continuous evaluation of

\footnotetext{
${ }^{*}$ Send correspondence to: Rafael Dias Loyola

Departamento de Ecologia,

Universidade Federal de Goiás - UFG, CP 131,

CEP 74001-970 Goiânia, GO, Brasil

e-mail: rdiasloyola@gmail.com
}

graduate programs by the Coordination for the Improvement of Higher Level Personnel (CAPES). Since 1998, CAPES developed a system for ranking scientific journals, called Qualis. Currently, categories (from high-level A1 to A2, B1 to B5 \& C) are primarily defined by the journals' IF (Marques 2009). Natureza \& Conservação is now classified as B2 (i.e. JCR indexed journals with IF < 0.90) in the Biodiversity committee, but will move to at least B1 category in the next version of the system because of the increasing IF. There is also a quality/quantity equivalence based on weighs of each category. For example, publishing two B2 papers, for example, weighs a bit more than publishing one A1 paper (IF > 2.87). Thus, quantity is emphasized, but quality is not absolutely neglected. The system is used to evaluate and rank graduate programs among Brazilian universities, and N\&C can now help a lot in this task. Further, we believe N\&C impact factor will rise even more. Our most cited paper was published in 2010, as well as all other top-five papers.

After only two years, it still is difficult to assess whether any of the papers have had an impact on conservation policy and practice. However, the Forum section allowed N\&C to trigger discussions that were important for our society (see papers in this section in vols. 8 and 9). The most prominent one were focused on the establishment of the new Brazilian Forest Act, whose flaws and scientific basis have been reviewed by Metzger (2010) and Magalhães et al. (2011). Local leaders and politicians have used the papers to discuss important issues rose by the scientific community in Brazil, with great media coverage (Metzger et al. 2010). Further, the section has highlighted the importance and commitments signed by Brazil in the last Conference of Parties from the Convention on Biological Diversity, which was held October 2010 in Nagoya, Japan (Mittermeier et al. 2010).

Recently, Brazil has led international negotiations setting ambitious global sustainable development targets, including the United Nations Conference on Sustainable Development, which returned to Rio de Janeiro this year after 20 years of the Rio Earth Summit of 1992 (Scarano et al. 2012). Nevertheless the federal government has made recent decisions that go against the policies that it advocates. Maybe this situation has lead to a political consensus that 
was above the expectations most conservationists and the civil society have (see the official document in http:// daccess-dds-ny.un.org/doc/UNDOC/GEN/N12/381/64/ PDF/N1238164.pdf?OpenElement). Brazil can contribute much to setting the scene on how to reconcile human well being and biodiversity protection because of its "economic stability, growing institutional capacity, a strong private sector, globally competitive academia and abundant natural capital" (Scarano et al. 2012). N\&C is ready to be a channel of scientific discussion on these themes.

After two years, we are very pleased with the journal. The papers are scientifically solid and may have a real impact on decision-making process. However, we still face challenges to maintain the high quality of content. First, we need to attract more contributions from other countries, especially from developing ones, where conservation problems are likely to be more difficult to solve. Second, as the journal becomes more diverse, we will need to broaden our horizons and scope to receive more papers related to biodiversity, not necessarily with a clear or direct conservation goal.

The success of N\&C depends on an enthusiastic support of the scientific community, which has been reflected by the submission of scientifically rigorous manuscripts to the journal. We, Editors-in-Chief, thank you very much for your support during the last two years.

\section{References}

Diniz-Filho JAF \& Loyola RD, 2010. Conservation Science in Brazil: Challenges for the 21st Century. Natureza \& Conservação, 8:1-2. http://dx.doi.org/10.4322/ natcon. 00801000

Magalhães ALB, Casatti L \& Vitule JRS, 2011. Alterações no Código Florestal Brasileiro Favorecerão Espécies Não-Nativas de Peixes de Água Doce. Natureza \& Conservação, 9:121-124. http://dx.doi.org/10.4322/natcon.2011.017

Marques F, 2009. A escala da discórdia: novos critérios do sistema Qualis, da Capes, recebem críticas da comunidade científica. PesquisaFAPESP, 160:32-34.

Metzger JP, 2010. O Código Florestal Tem Base Científica? Natureza \& Conservação, 8:92-99. http://dx.doi.org/10.4322/ natcon.00801017

Metzger JP et al., 2010. Brazilian law: full speed in reverse? Science, 329:276-277. http://dx.doi.org/10.1126/ science.329.5989.276-b

Mittermeier R et al., 2010. O Protagonismo do Brasil no Histórico Acordo Global de Proteção à Biodiversidade. Natureza \& Conservação, 8:197-200. http://dx.doi.org/10.4322/ natcon.00802017

Scarano F, Guimarães A \& Silva JM, 2012. Lead by example. Nature, 486:25-26. Pmid:22678263. http://dx.doi. org/10.1038/486025a 